\title{
Bioremediation of Heavy Metals from Artisanal Crude Oil Refinery (Kpo-Fire) Impacted Soil using Bacillus flexus and Pseudomonas aeruginosa in Ngie Community, Degema Local Government Area, Rivers State, Nigeria
}

\author{
*UGBOMA, CJ; SAMPSON, T; MBONU, NE \\ Department of Microbiology, Rivers State University, Nkpolu Oruworoku, Port Harcourt, Rivers State, Nigeria \\ *Corresponding Author Email: donchychy2007@yahoo.com
}

\begin{abstract}
The existence of heavy metals in "kpo-fire" impacted soil creates significant risks to human health and the ecosystem. In this study, the efficacy of the elimination of heavy metal from "kpo-fire" impacted soil was evaluated using bacterial treatments. The organisms (Bacillus flexus and Pseudomonas aeruginosa) used in the bioremediation setup were isolated from the impacted soil. Heavy metal analysis was carried out using an Atomic Absorption Spectrophotometer. The experimental setup involved the recreation of the contaminated soil sample in three (3) vessels labeled as: Flask A containing $300 \mathrm{~g}$ of un-amended sample (control) to monitor natural process; Flask B containing $300 \mathrm{~g}$ of sterilized sample; Flask C containing $300 \mathrm{~g}$ of sample with Pseudomonas aeruginosa and Bacillus flexus. Soil baseline physicochemical composition was determined to have a $\mathrm{pH}$ of 6.18 , Temperature of $29.2^{\circ} \mathrm{C}$, Total Organic Carbon $7.58 \mathrm{mg} / \mathrm{kg}$ and Phosphate concentration $37.56 \mathrm{mg} / \mathrm{kg}$. At the end of the investigation, experimental setup C, containing bacterial inocula was observed to possess the best bio-removal rates for Mercury (99.32\%), Cadmium (77.59\%), Boron (72.84\%) and Arsenic (93.43\%) after a 42-day period of study. Also, the concentrations declined from $1.05264 \mathrm{mg} / \mathrm{kg}$ to $0.00621 \mathrm{mg} / \mathrm{kg}$ for Mercury; Cadmium declined from $5.93 \mathrm{mg} / \mathrm{kg}$ to $1.16 \mathrm{mg} / \mathrm{kg}$; Boron declined from $3.61 \mathrm{mg} / \mathrm{kg}$ to $0.82 \mathrm{mmg} / \mathrm{kg}$ and Arsenic declined from $2.78 \mathrm{mg} / \mathrm{kg}$ to $0.16 \mathrm{mg} / \mathrm{kg}$. Molecular characterization revealed the contaminated soil had predominance of isolates with genomic molecular weight of 1,500 $\mathrm{bp}$ and the phylogenetic construct showed the bacterial isolates were Pseudomonas aeruginosa (MT023359), Bacillus flexus (MT023375) and Lysinibacillus macroides (MT023377). Statistical analysis revealed a strong positive correlation between the bacterial biomass and heavy metal removal. The synergistic parts played by bacterial consortia in the bio-removal of heavy metals from the polluted soil have been established and these potentials can be harnessed as a roadmap for eco-recovery of impacted environment in the Niger Delta. Bacillus flexus and Pseudomonas aeruginosa in consortium are efficient in remediation of kpo-fire contaminated soil.
\end{abstract}

DOI: https://dx.doi.org/10.4314/jasem.v24i12.6

Copyright: Copyright (C) 2020 Ugboma et al. This is an open access article distributed under the Creative Commons Attribution License (CCL), which permits unrestricted use, distribution, and reproduction in any medium, provided the original work is properly cited.

Dates: Received: 19 October 2020; Revised: 25 November 2020; Accepted: 07 December 2020

Keywords: Heavy Metal, bioremediation, impacted soil, eco-recovery, Pseudomonas aeruginosa, Bacillus flexus

Pollution caused by heavy metals is increasing with the increased usage of chemicals in industry and agriculture (Akbal and Camci, 2011). The existing heavy metals in the environment and industrial wastewater increasingly pollute the ecosystems and threaten human health in the developing countries. Several compounds have diverse properties such as $\mathrm{Zn}, \mathrm{Cu}, \mathrm{Ni}, \mathrm{Fe}$ and $\mathrm{Mn}$ and are essential trace elements for living organisms. The high-level accumulation of these metals if ingested in greater amounts than the required concentration can produce serious problem in living things including human being. In addition, heavy metals can cause severe toxic effects to exposed plants, animals and human when present in the excessive concentrations. The wastes containing metals are directly or indirectly being discharged into the environment producing serious environmental pollution and poses a major threat toward human, soil and sediments health (Siddiquee et al., 2015). "Kpofire" also known as illegal refinery or makeshift refinery is a slang used to describe illegal bunkering business striving in the Niger Delta region. "Kpo-fire" is coined from the explosive sound produced when fuel is poured on the fire. Waste from this "kpo-fire" are been discharged into our water bodies and mainland. The waste generally consists of organic compounds, inorganic complexes and other nonbridgeable substances (Ferre-Huguet et al., 2009; Deng et al., 2007). The untreated industrial waste disposal into environment affects quality of soil and ground water and well-thought-out as detrimental for soil use (Qazilbash, et al., 2006). These pollutants not only change the quality of soil and ground water but also pose severe problems (Karthikeyan et al., 2010; Gadd et al., 2001). There is increasing sense of global resolution concerning the environmental pollution by chemicals arrangement used in various activities (Palaniappan et al., 2009; Misra and Siddiqi, 2004; Paraszkiewicz et al., 2007). Wastewater produced from industrial treatment plant comprises significant 
metal pollutants. Their concentration must be condensed to levels that are conventional before being unconfined into the environment. Fast development has led to the rise of heavy metal disposal into the environment (Shipra et al., 2014). The ever-increasing activities associated with the local refining of petroleum products have inundated most environments with heavy metal. Pollution by these heavy metals could be associated with considerable damage to the public health and environment because of its non-biodegradability, less solubility, and toxicity for having carcinogenic and mutagenic effects. This study was therefore aimed at evaluating the Bioremediation of Heavy Metals from Artisanal Crude Oil Refinery (Kpo-Fire) Impacted Soil using Bacillus flexus and Pseudomonas aeruginosa in Ngie Community, Degema Local Government Area, Rivers State, Nigeria

\section{MATERIAL AND METHOD}

Sample Collection: Soil samples contaminated with "Kpo-fire" residue was collected in clean sterile container from a site in Ngie community, Degema Local Government Area of Rivers State. The depth of soil sample collected was $0-10 \mathrm{~cm}$. The sample was taken to the laboratory immediately after collection for immediate analysis.

Study Duration: The study duration was for six months. The study was carried out between the month of March, and September, 2019. The experimental set up was monitored for 42 days after isolation, purification and identification of the isolates.

Isolation of Bacterial Isolates: Aliquots $(0.1 \mathrm{ml})$ of 10 fold serially diluted samples of "kpo-fire" impacted soil were transferred to freshly prepared nutrient agar plates in triplicates. Inoculated plates were evenly spread with flamed glass spreaders and incubated at $37^{\circ} \mathrm{C}$ for 24 hours. After incubation, colonies that appeared on the plates were counted and the mean expressed as cfu/g for each sample. Discrete colonies were further purified by repeatedly sub-culturing unto fresh nutrient agar medium. Pure cultures were identified biochemically as described by Cheesbrough (2005). Further identification of isolates was done using molecular method.

Preparation of Bacterial Inoculum: The bacterial inoculum was prepared as described by Sampson et al., (2016). In this method, pure cultures of Bacillus sp and Pseudomonas sp was suspended in nutrient broth and incubated at $37^{\circ} \mathrm{C}$ for 24 hours. After which, $5 \mathrm{ml}$ each of the Bacillus flexus and Pseudomonas sp which has been adjusted to 0.5 McFarland standard was transferred into the experimental set up as shown below.

Three different treatment options were set up and labeled A-C in a sterile conical flask.

Flask A: contained $300 \mathrm{~g}$ of the original sample to monitor the natural process (Control).

Flask B: contained $300 \mathrm{~g}$ of sterilized sample (negative control)

Flask C: contained $300 \mathrm{~g}$ of sample with Pseudomonas sp. and Bacillus sp.

Molecular characterization of Isolates: The boiling method as described by Robinson and Wemedo (2019) was adopted in identification of bacterial isolates. In this method, pure bacterial isolate was inoculated into Luria Bertani (LB) broth and incubated for twentyfour hours. Five milliliters of the broth culture of the bacterial isolate in LB broth was spun at 14000rpm for 3 minutes. The cells were re-suspended in five hundred microlitres of normal saline and heated at $95^{\circ} \mathrm{C}$ for 20 minutes. The heated bacterial suspension was cooled on ice and spun for 3 minutes at 14000rpm. The supernatant containing the DNA was transferred to a $1.5 \mathrm{ml}$ microcentrifuge tube and stored at $-20^{\circ} \mathrm{C}$ for further use. The Nanodrop 1000 spectrophotometer was used in quantifying the recovered DNA. The 16s rRNA region of the rRNA gene of the isolates were amplified using the 27F: 5'AGAGTTTGATCMTGGCTCAG-3' and 1492R: 5'CGGTTACCTTGTTACGACTT-3' primers on an ABI 9700 Applied Biosystems thermal cycler at a final volume of 40 microlitres for 35 cycles. The PCR mix included: the X2 Dream taq Master mix supplied by Inqaba, South Africa (taq polymerase, DNTPs, $\mathrm{MgCl}$ ), the primers at a concentration of $0.5 \mathrm{uM}$ and the extracted DNA as template. The PCR conditions were as follows: Initial denaturation, $95^{\circ} \mathrm{C}$ for 5 minutes; denaturation, $95^{\circ} \mathrm{C}$ for 30 seconds; annealing, $52^{\circ} \mathrm{C}$ for 30 seconds; extension, $72^{\circ} \mathrm{C}$ for 30 seconds for 35 cycles and final extension, $72^{\circ} \mathrm{C}$ for 5 minutes. The product was resolved on a $1 \%$ agarose gel at $130 \mathrm{~V}$ for 30 minutes and visualized on a blue light transilluminator. Sequencing was done using the Big Dye Terminator kit on a 3510 ABI sequencer by Inqaba Biotechnological, Pretoria South Africa. Obtained sequences were edited using the bioinformatics algorithm Trace edit. Similar sequences were downloaded from the National Center for Biotechnology Information (NCBI) data base using BLASTN. These sequences were aligned using MAFFT. The evolutionary history was inferred using the Neighbor-Joining method in MEGA 6.0 (Saitou and Nei, 1987).

Heavy Metal and Physicochemical Parameter: The physicochemical parameters studied were 
temperature, $\mathrm{pH}$, biological oxygen demand (BOD), total organic carbon (TOC), phosphate concentration and nitrate concentration. The heavy metals such as Boron, Cadmium, Arsenic and Mercury were determined using an Atomic Absorption Spectrophotometer APHA (2012).

\section{RESULT AND DISCUSSION}

Molecular Identification of bacterial Isolates: The molecular profiling of the bacterial isolates revealed that the 16s rRNA sequence from the isolate showed an exact match during the megablast search for highly similar sequences from the NCBI non-redundant nucleotide (nr/nt) database. The evolutionary distances computed using the Jukes-Cantor method were in agreement with the phylogenetic placement of the 16S rRNA of the isolates B1, B2 and B3 within the Bacillus, Pseudomonas and Lysinibacillus sp respectively and revealed a close relatedness to Bacillus flexus, Pseudomonas aeruginosa and Lysinibacillus macrolides, respectively (Fig. 1). The agar rose gel electrophoresis of the 16SRNA gene of the bacterial isolate is presented in Plate 1.

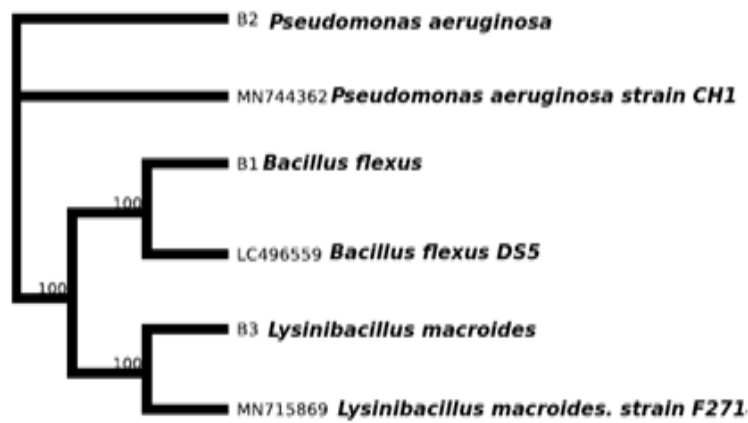

Fig 1. Phylogenetic construct of bacterial isolates obtained from Kpo-fire impacted soil

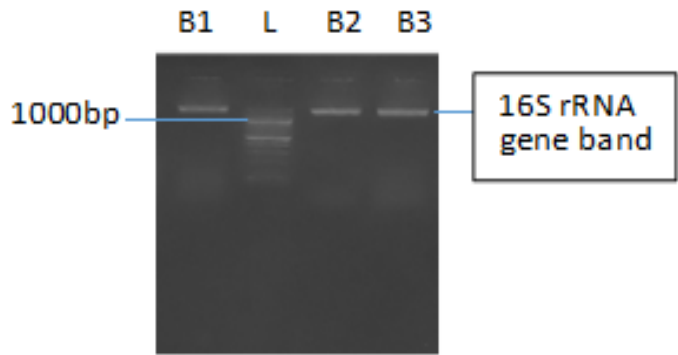

Plate 1: Agarose gel electrophoresis of the 165 rRNA gene $f$ some elected bacterial isolates. Lanes B1, B2, B3 represent the 165 rRNA gene bands (1500bp), lane L represents the 100bp molecular ladder

Microbial dynamics during bioremoval activity: The results presented in Fig 2 represents the changes in the microbial population in the experimental setup. Total heterotrophic bacterial count of the experimental setup was observed to increase throughout the period of study. The setup A (control), showed a gradual increase from $7.48 \mathrm{Log} 10 \mathrm{Cfu} / \mathrm{g}$ at the beginning of the study to $7.7 \mathrm{Log} \mathrm{Cfu} / \mathrm{g}$ after a 42 day period. The $\mathrm{p}$ value of 0.035 , degree of freedom of 3.0 and F-value of 5.59 indicates that there was a significant difference in the microbial quality of the different treatments.

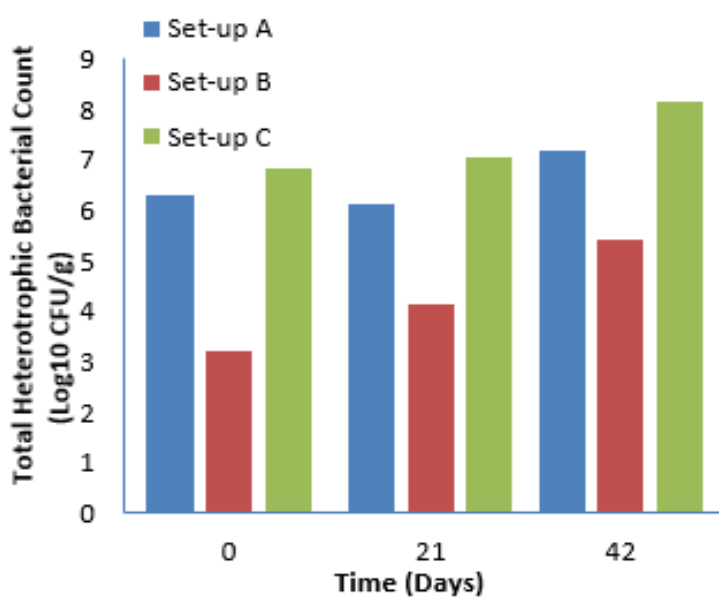

Fig 2. Total heterotrophic Bacterial count during the bioremoval of heavy metals. Flask A $300 \mathrm{~g}$ of the original sample to monitor the natural process (Control); Flask B 300g of sterilized sample (negative control), Flask C $300 \mathrm{~g}$ of sample with Pseudomonas sp. and Bacillus sp. 0

Bioremoval of Heavy Metals: The results for the bioremoval of heavy metals as presented in fig 3 to fig 10 showed high level of bioremediation of the heavy metals by the Bacillus and Pseudomonas consortium. Cadmium which had a concentration of $5.17 \mathrm{mg} / \mathrm{kg}$ in day 0 was reduced to $1.16 \mathrm{mg} / \mathrm{kg}$ in the $42^{\text {nd }}$ day (fig. $3)$. Arsenic was equally reduced from the initial concentration of $2.39 \mathrm{mg} / \mathrm{kg}$ in day 0 to $0.16 \mathrm{mg} / \mathrm{kg}$ in the $42^{\text {nd }}$ day of remediation (fig. 4). More so, Boron and Mercury were greatly reduced by the activities of Bacillus and Pseudomonas consortium as illustrated in fig 5 and 6, respectively. Although the natural attenuation process of bio-removal slightly reduced the concentrations of the heavy metals in the soil, its effect was not highly pronounced as compared to the impact or effect recorded for the bacterial consortium. Crude oil refinery activities and their associated pollutant have been reported to have devastating effect on both fauna and flora (Hart, 2018; Odokuma, 2012). Artisanal refineries constitute one of the emerging pollutant sources in the Niger Delta as these activities have remained largely under-reported, concealed and organized in Nigeria (Hart, 2018). One of the immediate and obvious evidence is the presence of oilslick in aquatic and terrestrial ecosystems thereby affecting the physicochemical and economic activities of peasants in the ecosystem. In this present study, the $\mathrm{pH}$ of the kpo-fire impacted soil was 6.9, the temperature was $24.91{ }^{\circ} \mathrm{C}$. Electrical conductivity was 
$980.74 \mu \mathrm{S} / \mathrm{cm}$. These values agree very strongly with the report of Eze et al. (2018), that $\mathrm{pH}$ at alkaline condition increases the sorption and bioavailability of nutrients to the microbiota.

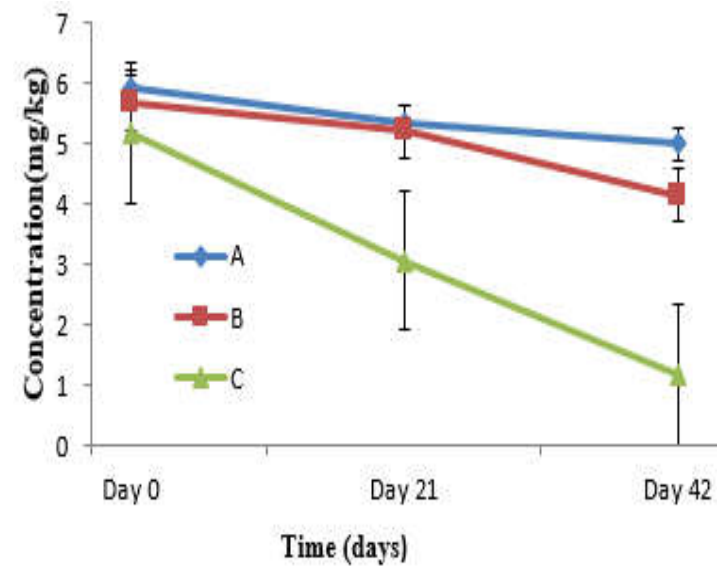

Fig 3. Bioremoval of Cadmium (Cd): Flask A $300 \mathrm{~g}$ of the original sample to monitor the natural process (Control).; Flask B 300g of sterilized sample (negative control), Flask C $300 \mathrm{~g}$ of sample with Pseudomonas sp. and Bacillus sp.

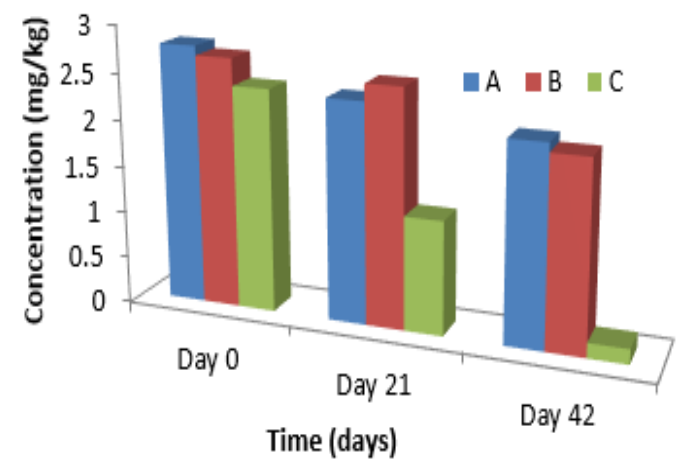

Fig 4. Bioremoval of Arsenic: Flask A 300g of the original sample to monitor the natural process (Control); Flask B $300 \mathrm{~g}$ of sterilized sample (negative control), Flask C $300 \mathrm{~g}$ of sample with

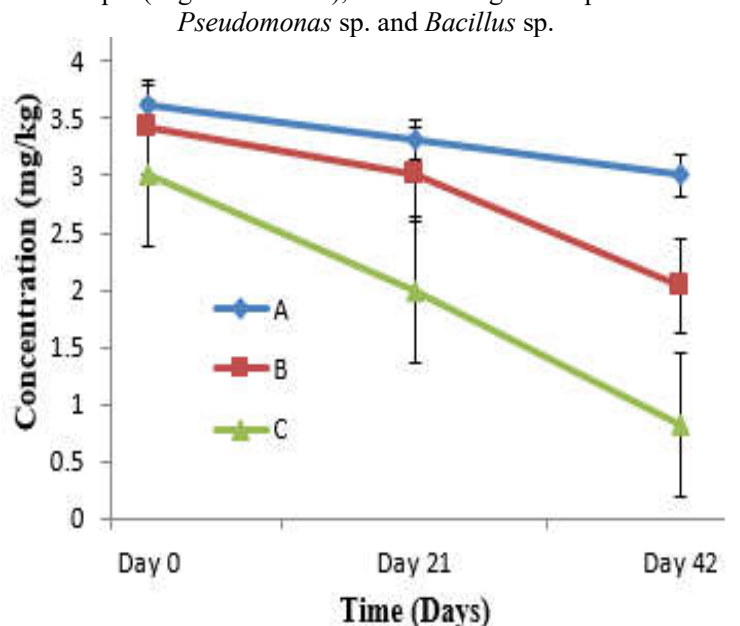

Fig 5. Bioremoval of Boron: Key: Flask A $300 \mathrm{~g}$ of the original sample to monitor the natural process (Control).; Flask B 300g of sterilized sample (negative control), Flask C $300 \mathrm{~g}$ of sample with Pseudomonas sp. and Bacillus sp.

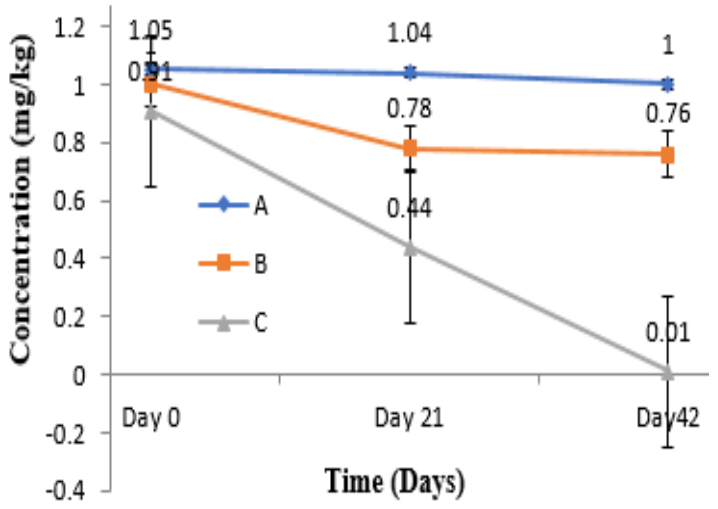

Fig 6. Bioremoval of Mercury: Key: Flask A $300 \mathrm{~g}$ of the original sample to monitor the natural process (Control).; Flask B 300g of sterilized sample (negative control), Flask C $300 \mathrm{~g}$ of sample with Pseudomonas sp. and Bacillus sp.

These parameters are crucial in the monitoring of the environmental quality of a media especially in the interaction of exchangeable cations, while the temperature factor indicates the solubility of nutrients and formation of metal-oxide complexes (Orhohoro et al., 2018). Furthermore, Chima and Vure (2014) suggested that the $\mathrm{pH}$ and temperature indices of the soil were also related to the geochemical indices such as the soil pore-sizes, air-quality and permeability (Effiong et al., 2019). The concentration of Boron in the soil sample was $3.6 \mathrm{mg} / \mathrm{kg}$; Mercury was $1.05 \mathrm{mg} / \mathrm{kg}$ with the DPR target value of $0.30 \mathrm{mg} / \mathrm{kg}$ and intervention value of $10 \mathrm{mg} / \mathrm{kg}$. Furthermore, Arsenic was $2.78 \mathrm{mg} / \mathrm{kg}$; Chromium was $24.11 \mathrm{mg} / \mathrm{kg}$ and cadmium were 5.93 with intervention values within $10-17 \mathrm{mg} / \mathrm{kg}$. Some of values of the "Kpo-fire" impacted soil are above the DPR values for soil. The values reported in the present study corroborate the account of Ogbo (2011) that the presence of the pollutants has the potential of increasing the electrical conductivity due to the presence of radicals, unstable compounds and ions. Microbial qualities of soil represent real-time biomonitors of soil viability for agricultural activities. Total heterotrophic bacterial count in the present study of was $1.26 \times 105 \mathrm{CFU} / \mathrm{g}$. These counts agree with the report of Ataikiru et al. (2018) whose report documented the hydrocarbon utilizing bacterial count was within the range of 3.0$5.0 \log _{10} \mathrm{CFU} / \mathrm{g}$. This also agrees with the report of Chikere and Ekwuabu (2014) whose study alluded to the same range. Udume et al. (2019) reported that diesel polluted soil obtained from the generator house in Delta Campus of the University of Port Harcourt could have a microbial count with the same range of 3.0-5.0 $\log _{10} \mathrm{CFU} / \mathrm{g}$ of the polluted soil.

Bacterial diversity of the polluted soil has been reported to have a difference between the polluted and 
the pristine. The presence of bacterial isolates namely B. subtilis, Pseudomonas. sp., Micrococcus sp., Staphylococcus sp. Paenibacillus sp. and Bacillus. sp are notably associated with several polluted environments. Some of the isolates Pseudomonas aeruginosa and Bacillus sp. have been reported in some articles to produce organic materials that possess biosurfactant or emulsification properties and thereby increasing the solubility and bioavailability of components for microbial activities (Effiong et al., 2019; Sampson et al., 2016). This study agrees strongly with the report of Udume et al. (2019) who reported the preponderance of Bacillus spp and Pseudomonas sp from their separate investigations, especially spore formers. This further concretizes the report of Orji et al. (2018) that microbes and their diversity correlate with the diversity of organic substances produced as a result of adaptation to the environmental fluxes. The reports of Giwa and Ibitoye (2017) were in tandem with the current study that the microbial diversity of polluted environmental media was pivotal or vital to the bioremoval of contaminants that can impede the futuristic usage of the soil.

Microbial population dynamics during the bioremoval activities observed in this study showed that there was no significant difference $(p>0.05)$ in the increase in the population of the bacterial consortia. There was an increase in the bacterial population from the initial day (day 0 ) to the final day ( $42^{\text {nd }}$ ) for setup $\mathrm{C}$, this could be attributed to microbial metabolism and conversion of spent metabolites and intermediates. This agreed with Odokuma (2012) who also opined that microbial population dynamics is related to microbial metabolism and conversion of metabolites from the source of energy. The report of Stanley et al. (2018) whose report supported that there was an increase in fungal biomass as bioremediation of total petroleum hydrocarbon (TPH). It was also in a previous study conducted by Stanley et al. (2017) using combinations of agro-residues and spawn of Pleurotus sp. The work of Sampson et al. (2016) suggests that microbes converting harmful pollutants into less harmful ones follow a predictable and model-feasible bioprocess. According to Osuji and Onojake (2004), the bioavailability of heavy metals in polluted soil is controlled by the absorption coefficients and geophysical factors. In their study, conducted in Ebocha II polluted sites in Rivers, Nigeria. Their report revealed the concentration of Lead $(\mathrm{Pb})$ varied between 0.32 to $0.8 \mathrm{mg} / \mathrm{kg}$ surficial and sub-surfacial soil. Cadmium and Nickel were $<0.02 \mathrm{mg} / \mathrm{kg}$. Mercury was $1.05 \mathrm{mg} / \mathrm{kg}$; Zinc was $28.17 \mathrm{mg} / \mathrm{kg}$. In this present study, the concentration of Cadmium and iron was $3.01 \mathrm{mg} / \mathrm{kg}$ and $143.18 \mathrm{mg} / \mathrm{kg}$, respectively. The results concur with the report of Ogbo and
Okhuoya (2011) whose report observed the zinc concentration to be in the range of $20-30 \mathrm{mg} / \mathrm{kg}$ in polluted soils and suggested that these amounts could support microbiota.

Conclusion: This study has shown that Bacillus flexus and Pseudomonas aeruginosa are efficient in the bioremediation of kpo-fire contaminated soil. Also, extended period of remediation using these organisms in consortia would yield more progress in the removal of the heavy metals in kpo-fire contaminated soil based on the findings in this study.

\section{REFERENCES}

Akbal, F; Camci, S. (2011). Copper, chromium and nickel removal from metal plating waste water by electrocoagulation. Des. 269: 214-222.

Ataikiru, T L; Okerentugba, P O; Iheanacho, C C (2018). Bioremediation of bonny light crude oil polluted soil by bioaugmentation using yeast isolates (Candida adriatica ZIM 2468 and Candida taoyuanica MYA-4700). Int J Pub Env Health. 5(4), 52-61.

Cheesebrough, M (2005). District Laboratory Practice in Tropical Countries. Part 2, Cambridge University Press, London, UK. Pp 143 - 156.

Chikere, C B; Ekwuabu, C B (2014). Culturedependent characterization of hydrocarbon utilizing bacteria in selected crude oil-impacted sites in Bodo, Ogoniland, Nigeria. Afri J Env Sci and Tech. 8(6), 401-406.

Chima, U D; Vure, G (2014). Implications of crude oil pollution on natural regeneration of plant species in an oil-producing community in the Niger Delta Region of Nigeria. J forestry res, 25(4), 915-921.

Deng, L., X. Zhu, X., Wang, Y. S. and Su, H. (2007). Biosorption of copper (II) from aqueous solutions by green alga Cladophora fascicularis. Biodegradation, 18: 393-402.

Effiong, E; Agwa, O K; Abu, G O (2019). Nicheproxies of Hydrocarbon-impacted Rhizosphere Soil of Weeds of Bodo in Gokana, Rivers State, Nigeria. Arch of Curr Res Intl, 1-14.

Eze, C; Odoh, C; Eze, E; Orjiakor I; Enemuor, S; Okobo, U (2018). Chromium (III) and its effects on soil microbial activities and phytoremediation potentials of Arachis hypogea and Vigna unguiculata. Afric J Biotech. 17, 1207-1214. 
Ferre-Huguet, N C; Bosch, C; Lourencetti, M; Nadal, M; Schuhmacher, J O; Grimalt; Domingo J (2009). Human health risk assessment of environmental exposure to organochlorine compounds in the Catalan stretch of the Ebro River, Spain. Bulletin of Env Cont and Toxic. 83: 662-667.

Gadd, G M; Ramsay, L; Crawford, J W; Ritz, K (2001). Nutritional influence on fungal colony growth and biomass distribution in response to toxic metals. FEMS Microb Let. 204: 311-316.

Giwa, O E; Ibitoye, F O (2017). Bioremediation of heavy metal in crude oil contaminated soil using isolated Indigenous microorganism cultured with E coli DE3 BL21. Intl J Eng and App Sci. 4(6).

Hart, A I (2018). The Unsung Heroes Our Time. Inaugural Lectures Series. No148. Uniport Press. pp 46-60

Karthikeyan, K; Chandran, C;.Kulothungan, S (2010). Biodegradation of oil sludge of petroleum waste from automobile service station using selected fungi. J Ecotoxic. Environ. Mon. 20: 225-230.

Odokuma, L O (2012). The genius in the microbe: an indispensable tool for the management of xenobiotic mediated environmental flux. Inaugural. Lecture Series: (87).

Ogbo, E M; Okhuoya, J A (2011). Bioavailability of some heavy metals in crude oil contaminated soils remediated with Pleurotus tuber-regium Fr. Singer. Asian j of Biolo. Sci. 4(1), 53-61.

Orhorhoro, E; Effiong, E; Abu, G (2018). Laboratoryscale bioremediation of crude oil polluted soil using a consortia of rhizobacteria obtained from plants in Gokana-Ogoni, Rivers State. $J$ of $A d v$ Microb. 9, 1-17.

Orji, C N; Abdulrahman, F W; Isu, N R (2018). Assessment of heavy metal pollution in soil from an automobile mechanic workshop in Abuja. Asian J of Env \& Ecol. 1-14.
Osuji, L C; Onojake, C M (2004). Trace heavy metals associated with crude oil: A case study of Ebocha8 Oil-spill-polluted site in Niger Delta, Nigeria. Chem \& bio. 1(11), 1708-1715.

Qazilbash, A; Faryal, R; Naqvi, K; Ahmad, S; Hameed, A (2006). Efficacy of indigenous Bacillus species in the removal of chromium from industrial effluent. Biotech. 5: 12-20.

Robinson, V K; Wemedo, S A (2019). Molecular Characterization of Indoor Air Microorganisms of a Model Primary Health Care in Port Harcourt, Rivers State, Nigeria. Asian J. Biotech and Genetic Engine. 2(1): 1- 9

Saitou, N; Nei, M (1987). The neighbor-joining method: A new method for reconstructing phylogenetic trees. Molecular Biolo and Evolu 4:406-425.

Sampson, T; Ogugbue, C J; Okpokwasili, G C (2016). Simulating biodegradation of hydrocarbon pollutants under slow nutrient delivery conditions. Microb Res J Intnl, 14(5):1-8.

Shipra, J; Ritu C; Dikshit, S (2014). Fungal Biomass as Biosorbent for Removal of Heavy Metal from Industrial Wastewater Effluent. Asian J. Plant Sci. 13 (2): 93-97.

Siddiquee, S; Rovina K; Azad, S; Naher, L; Suryani S. (2015) Heavy Metal Contaminants Removal from Wastewater Using the Potential Filamentous Fungi Biomass: A Review. Journal of Microb and Bioch Techn. 7:384-393.

Stanley, H O; Ihennacho, C M; Stanley, C N (2017). Bioremoval of heavy metals from effluent of Port Harcourt Refinery using Pluerotus ostreatus. J. of Petrol and Env Biotech. 7, 324.

Udume, O A; Effiong, E; Abu, G O (2019). Degradation Kinetics of Microbial Consortium Isolated from Diesel Oil Impacted Soil in Delta Park, University of Port Harcourt, Nigeria. Microb Res J. Int. 1-15. 